\title{
Morphological, Anatomical, and Chemical Characteristics Associated With Lodging Resistance in Avena Sativa
}

Jéssica Argenta ( $\sim$ jessicarargenta@gmail.com )

UFRGS: Universidade Federal do Rio Grande do Sul https://orcid.org/0000-0001-7838-6757

Marcelo Teixeira Pacheco

UFRGS: Universidade Federal do Rio Grande do Sul

Jorge Ernesto de Araujo Mariath

UFRGS Departamento de Botanica: Universidade Federal do Rio Grande do Sul Departamento de Botanica

\section{Luiz Carlos Federizzi}

UFRGS: Universidade Federal do Rio Grande do Sul

\section{Research Article}

Keywords: Oat, culm thickness, culm length, subdermal parenchyma

Posted Date: April 30th, 2021

DOl: https://doi.org/10.21203/rs.3.rs-381075/v1

License: (9) This work is licensed under a Creative Commons Attribution 4.0 International License. Read Full License

Version of Record: A version of this preprint was published at Euphytica on February 4th, 2022. See the published version at https://doi.org/10.1007/s10681-022-02971-8. 


\section{Abstract}

In subtropical environments, lodging occurs at all stages of an oat plant development, particularly after panicle's appearance, causing severe yield reduction. This study's objective was to identify the morphological, chemical, and anatomical characteristics of the culm that are associated with lodging resistance in oats and that can be used to identify and select resistant genotype. A set of different genotypes with diverse response to lodging were grown in nine environments, combining sowing densities, years, and growing seasons within the same year. Were carried out morphological, anatomical, and chemical evaluations for primary culms. Shorter culm length and larger culm thickness in the first expanded basal internode are morphological characteristics associated with lodging resistance in Avena sativa. No differences in lignin and cellulose contents were observed, however, there were differences in the distribution pattern and in the intensity of staining of lignin and cellulose. Resistant genotypes showed higher number of layers of cells in the subdermal parenchyma. The most practical and easily selectable feature for lodging resistance in a breeding program remains plant height together with culm thickness in the first basal internode.

\section{Introduction}

Oats are the fifth-most cultivated cereal, and they are among the top ten annual crops in Brazil. In recent years, oat farming has grown in cultivated areas, production, and productivity (USDA, 2020). Currently, Brazil ranks among the leading world producers of oats, with production destined exclusively for the Brazilian market (Lima, 2019). Oats are an alternative to wheat for cultivation in winter, mainly due to their higher profitability (Lima, 2019), easier marketing, and their benefits for the no-till system (Fontanelli, 2012).

The lodging of plants is a limiting factor for grain yield in cereals, including oats; therefore, resistance to lodging is a primary objective of cereal improvement programs (Berry \& Spink, 2012). Defined as the permanent displacement of the culms' vertical position (Pinthus, 1967), lodging is caused by the bending of the stalk, breaking of the base of the stalk, or root displacement in the soil (Berry \& Spink 2012).

In temperate climates, lodging occurs after the panicle's appearance and is more common during grain filling (White, 1995; Tams, Mooney, \& Berry, 2004; Berry \& Spink, 2012). The yield reduction during the grain filling period is about $0.5 \%$ per day (Stapper \& Fischer, 1990), and losses can reach $80 \%$ (Foulkes et al., 2011). These losses result directly from interference with the accumulation of the grains' dry matter, a decrease in the number of grains per square meter, and less filling of the grains; indirectly, losses result from difficulties in harvesting, loss of grain quality, and higher drying costs (Zuber et al., 1999; Berry \& Spink, 2012). In subtropical environments, lodging occurs at all stages of plant development, particularly after tillering, and this is relatively common in oat crops.

The strong winds associated with precipitation are the primary causes of lodging (Tams, Mooney, \& Berry, 2004). Nevertheless, lodging is a complex phenomenon that results from the interaction of climatic 
conditions with several factors intrinsic to the genotype, soil characteristics, and cultivation practices (Tams, Mooney, \& Berry, 2004; Berry et al., 2000).

Reduction of plant height is the primary strategy used by breeding programs to reduce lodging in cereals. Nevertheless, several factors related to the genotype contribute to lodging resistance, including the cellulose, hemicellulose, and lignin contents that make up the culm cell walls, the lengths and numbers of internodes, and the diameter and thickness of the culm (White, 1995; Tripathi et al., 2003; Zhu et al., 2004; Kong et al., 2013). Other anatomical characters are related to lodging resistance, including parenchymal and sclerenchymal tissues, the cellular organization in these tissues cell proportion, and numbers of vascular bundles (Kong et al., 2013; Hasnath \& Jahan, 2013).

Although there has been extensive research on lodging in cereals, especially wheat and barley in temperate environments, the lodging of plants in oats remains poorly understood, especially for oats grown in sub-tropical environments.

This study's objective was to identify the morphological, chemical, and anatomical characteristics of the culm that are associated with lodging resistance in oats and that can be used to identify and select resistant genotype.

\section{Materials And Methods}

\subsection{Description of the experimental area}

The experiments were conducted at the Experimental Agronomic Station of UFRGS, in Eldorado do Sul $\left(30^{\circ} 05^{\prime} 52^{\prime \prime} \mathrm{S}, 51^{\circ} 39^{\prime} 08^{\prime \prime} \mathrm{W}\right)$. The average altitude is 46 meters above sea level and the climate of the region is Köppen-Geiger type Cfa (subtropical humid), with an average annual precipitation of approximately $1400 \mathrm{~mm}$. The months with the most rain are June, July, and August. The soil of the experimental area is characterized as typical Red Dystrophic Argisol (EMBRAPA, 1999).

\subsection{Plant material and experimental design}

We evaluated five elite oat genotypes (Avena sativa), developed by the Oat Breeding Program at UFRGS, including three cultivars and two inbred lines, in 2017 and 2018. The evaluated genotypes possessed varying levels of resistance to lodging and plant heights (Table 1).

The experiment was carried out in nine environments, combining sowing densities, years, and growing seasons within the same year (Figure 1). Sowing in 2017 occurred on June $23^{\text {rd }}$. In 2018, sowing occurred on June $21^{\text {st }}$ (season 1 ) and July $13^{\text {th }}$ (season 2 ).

The experimental design followed a randomized block pattern with four replications in a factorial scheme of five (genotypes) $x$ three sowing densities each year $(150,300$, and 450 seeds able to germinate per meter squared). 
We used different sowing densities to determine whether the increase in the number of culms per area or competition for resources would influence tillering and cause significant morphological and anatomical changes in the genotypes, increasing or decreasing the risk of lodging. We used various sowing times, and their influences on oat culms' morphology and anatomy and their direct influences on lodging.

TABLE 1. Genotypes, height, resistance levels, and resistance scales.

\begin{tabular}{|llll|}
\hline Genotype & Height & RL & RS \\
\hline UFRGS 127013-1 & Average & S & 1 \\
\hline URS 21 & Tall & MS & 2 \\
\hline URS Altiva & Very tall & MR & 3 \\
\hline UFRGS 146155-1 & Average & R & 5 \\
\hline URS Taura & Short & R & 5 \\
\hline
\end{tabular}

RL: Resistance level; RS: Resistance scale; S: susceptible; MS: moderately susceptible; MR: moderately resistant; R: resistant. The resistance scale ranged from 1 to 5 , with 1 being susceptible and 5 being resistant. URS refers to the cultivars, and UFRGS refers to the imbreed lines from the UFRGS Oat Breeding Program. Source oat breeding program at UFRGS, 2017.

The experiments were conducted using the no-tillage system. Basic fertilization followed the recommendations provided by the analysis of soil and $350 \mathrm{~kg} \mathrm{ha}^{-1}$ using the formula 5-30-15 of the Nitrogen, Phosphorus and Potassium, respectively. Top dressing of Nitrogen was divided into two applications, when the plants reached three and six fully expanded leaves, totaling $70 \mathrm{~kg} \mathrm{ha}^{-1}$ of $\mathrm{N}$, using urea.

Chemical control of diseases occurred whenever there was a need for control or prevention recommended by the Brazilian Oat Research Commission.

\subsection{Morphological evaluation}

We collected five plants from each experimental unit during flowering in all environments, at random, maintaining the roots and soil moist. We used the following parameters for primary culms: total culm length (TCL), corresponding to the distance from the plant's base to the insertion of the panicle; in the first and second basal internodes culm diameter (DFI, DSI) and culm thickness (TFI; TSI) in the median portion of each internode, and length of each internode (LFI, LSI).

For measurements, the leaves and leaf sheaths were removed. We measured culm diameter, culm thickness, and internode length using a digital caliper. 
Evaluation of lodging occurred weekly according to the angle with the ground and percentage of the experimental unit lodged. However, in 2017, there was a storm after flowering, with strong winds above $100 \mathrm{~km}$ per hour, making this type of analysis infeasible. In 2018, lodging did not occur uniformly in the experimental area; therefore, we chose not to use lodging data; instead, we used prior knowledge about the level of resistance of the genotypes obtained from the oat breeding program of UFRGS.

Grain yield were measured harvesting mechanically plots and after the yield was estimated in kilograms per hectare $\left(\mathrm{kg} \mathrm{ha}^{-1}\right)$.

\subsection{Anatomical and chemical evaluations}

In 2018, we performed anatomical evaluations for the five genotypes conducted in the field in environments 5 and 8 . We chose these environments because they represent different seasons with the average sowing density to cultivate oats in southern Brazil (300 seeds per meter squared).

To determine the anatomical characters, cross-sections of approximately $20 \mu \mathrm{m}$ were cut freehand in the middle portion of the first basal internode. We collected the internodes at the flowering stage, fixed them in $70 \%$ ethyl alcohol $90 \%+5 \%$ acetic acid $+5 \%$ formaldehyde, and examined them under a light microscope equipped with a digital camera at 10X magnification. Each genotype was represented by ten cross-sections of the first basal internode. We identified tissue types according to the nature of their composition. In Poaceas do not have distintal separation between parenchyma tissues. Nevertless, it was decided to divide the tissues into cortical and medullary parenchyma due to the presence of a gradient in size, thickness, and cell composition. Using a 40X stereomicroscope equipped with a digital camera we counted the number of cell layers of the subdermal parenchyma (SP), the number of cell layers of the sclerenchyma ring (SR), the number of cell layers of the cortical parenchyma (CP), number of cell layers of the medular parenchyma (MP), number of total vascular bundles (VB), and number of layers of total cells (LC).

We used phloroglucinol and hydrochloric acid solution for visualization under a bright-field microscope for the histochemical localization of lignin. The appearance of the red color indicated the presence of lignin. For cellulose, we used calcofluor solution and evaluated the sections under a fluorescent microscope. The appearance of fluorescent blue coloring indicated the presence of cellulose in the cell walls. The analyses were carried out in the plant anatomy laboratory of the UFRGS Biosciences Institute.

To perform chemical analysis, plants were collected in a linear meter of each experimental unit at the fullflowering stage, with the leaves and leaf sheaths removed. Subsequently, we dried the culms in a forcedventilation oven at $65^{\circ} \mathrm{C}$ until achieving a constant mass. The culms were ground for further analysis at the Food Research Center at the University of Passo Fundo, RS. We analyzed oat plant culms for lignin, neutral detergent fiber, and acid detergent fiber contents to estimate approximate cellulose concentrations, calculated according to Silva \& Queiroz (2009). 
There were short periods of drought in 2017 in the second half of June and at the ends of July and August. That year, the average monthly temperatures were 14.7, 16.2, and 19.5 for July, August, and September, respectively (flowering). The temperature peaks above $30^{\circ} \mathrm{C}$ occurred in September, the month of plant flowering. The aggregate rainfalls in these months were 26.8, 95.6, and $143.0 \mathrm{~mm}$, respectively.

In environments 4, 5, and 6 in 2018, rainfall until flowering was approximately $80 \mathrm{~mm}$ higher than in environments 7,8 , and $9(153.6,121.4$, and $183.4 \mathrm{~mm}$, respectively); these average values corresponded to July, August, and September, respectively. The maximum temperatures occurred after flowering (10-18 September), with monthly averages of $13.7,13.5$, and $18.7^{\circ} \mathrm{C}$ for July, August, and September, respectively, milder than those of 2017.

The average photosynthetically active radiation during emergence until flowering in 2017 was $685 \mu \mathrm{mol}$ $\mathrm{m}^{-2} \mathrm{~s}^{-1}$. The average photoperiod was approximately 11 hours and 20 minutes. In 2018, the average photosynthetically-active radiation was $584 \mu \mathrm{mol} \mathrm{m} \mathrm{m}^{-2} \mathrm{~s}^{-1}$; this reduction was primarily due to the more significant number of rainy days that year. The average photoperiod was approximately $11 \mathrm{~h} 15 \mathrm{~min}$.

\subsection{Statistical analysis}

We performed an analysis of variance for all parameters in various environments using SAS 8.0 (SAS Institute. Inc., 2000), with the 'PROC GLM' procedure. We compared means using the Duncan multiple comparison test when no significant interaction was detected. Both tests were performed at a $5 \%$ and $1 \%$ probability of error. Possible interactions were between genotypes, densities, and cultivation environments.

We calculated Spearman correlation coefficients to determine the degree of association between the ordering of the values and the characters evaluated, using the procedure 'PROC CORR,' option 'SPEARMAN' in SAS 8.0 (SAS Institute. Inc., 2000). We tested the relationships between resistance to lodging and the five genotypes' morphological characters using multiple linear regression analysis. The lodging notes were used as the dependent variables, and the morphological characters were used as the independent variables. We performed principal component analysis using PAST 3.26 software (Hammer et al., 2001).

In addition to these quantitative analyses, we performed qualitative visual analyses of the photos taken from the anatomical sections to identify the genotypes' differences in terms of lignin and cellulose contents.

\section{Results}

\subsection{Morphological characteristics}


Morphological data for the five oat genotypes are shown in Figure 2. There was a significant interaction between genotype $x$ environment $(p=0.01)$ for all evaluated characteristics, which are dependent on the growing season in which the oat plants are grown. This variation was significant between the genotypes; however, the differences between genotypes were not always significant between the tested environments (Figures 1a-d, Supplementary Table 2). The resistant genotypes, regardless of the evaluated environment, presented lower culm length (Figure 2a) and higher culm thickness (Figure 2d, Supplementary Table 2). More significant differences between resistant and susceptible genotypes concerning the length of internodes were observed in LFI (Figure 2b), with resistant genotypes showing lower averages, particularly in environments 1, 2, and 3 during the 2017 harvest.

The first internodes were shorter with smaller diameters and greater thicknesses than the second internodes. Mean culm thicknesses in the resistant genotypes were highest in environments 1, 7, and 9. The indices of genotypes' lodging resistance (Supplementary Table 4) had significantly negative correlations with culm length $\left(R^{2}-0.60\right)$ and length of internodes $(\mathrm{LFI}, \mathrm{LSI})\left(\mathrm{R}^{2}-0.48 ;-0.45\right)$.

In grain yield, do not have differences between genotypes. On the other hand, differences were observed between environments (Supplementary Figure 6).

The lodging resistance index significantly positively correlated with culm diameters (DFl; DSI) $\left(R^{2} 0.43 ; R^{2}\right.$ $0.70)$ and culm thicknesses (TFI, TSI) $\left(R^{2} 0.59 ; R^{2} 0.49\right)$.

In multiple linear regression analysis, the culm diameter at first internode (DFI) and the culm thickness at first internode (TFI) explained $51 \%$ of the variation in the lodging resistance index (Supplementary Table 5).In the analysis of the main components, the total culm length (TCL) explained $83.3 \%$ of the morphological data variation (Supplementary Figure 4 ). Another $10.12 \%$ was explained by the length of the first expanded basal internode (LFI). Other components completed the remainder of the total variation (Supplementary Table 3).

\subsection{Histochemical location, anatomical features, and chemical composition}

Lignin is primarily present in parenchymatic tissues with thicker cell walls and the Sclerenquima ring and Bundle sheath sclerenchyma (Figure $4 \mathrm{a}-\mathrm{d}$ ). The resistant genotypes had higher levels of lignin, based on visual inspection of the histological photographs. However, there were no significant differences in lignin content between the resistant and susceptible genotypes in chemical analysis (Supplementary Figure 4). In addition, there was more significant development of cell layers in the SP, accompanied by more significant presence of cellulose in lodging-resistant genotypes (Figure $5 c-d$, Supplementary Table 5). Nevertheless, the chemical analysis of cellulose contents did not reveal significant differences between genotypes.

For the sclerenchymal ring, the genotypes UFRGS 127013-1 (susceptible) and URS Taura (resistant) did not differ from each other in the first sowing season (environment 5), while UFRGS 127013-1 was superior to URS Taura in the second season (environment 8). Thus, although the sclerenchymal ring 
provides mechanical support, the number of cell layers in sclerencyma ring it does not appear to be directly associated with differences in lodging resistance and is influenced by the environment. Regarding number of layers in sclerenchymal ring, environment 5 presented higher averages than environment 8 , suggesting that the character expression depends on the sowing time (Supplementary Table 6).

The number of vascular bundles was not related to lodging resistance; however, it changed under the environment's influence (Supplementary Table 5).

\section{Discussion}

Shorter culm length (LFI) and greater culm thickness (TFI) of the first expanded basal internode were characteristics of the lodging-resistant genotypes (Figure 1a-d). This finding was also associated with lodging resistance in wheat and rice (Kelbert et al., 2004; Kong et al., 2013; Shah et al., 2017).

The increase in the number of plants per square meter resulted in an increase in total culm length, simultaneously with a decrease in culm thickness (environments 3, 6, and 9; Figure 2a, 2d). Even with an increase in the number of plants per meter squared, the culm thickness was more stable in resistant genotypes. These results suggest that the decrease in sowing density can reduce the lodging rates in oats by reducing culm length and increasing culm diameter. Although some authors recommend this practice (Berry; Sylvester-Bradley; Berry, 2007; Shah et al., 2017), it may not be compatible with maximizing grain yield. In your data, differences in grain yield do not occur because of different sowing density. However, we observed an increasing of grain yield with rising sowing density (300 and 450 seeds able to germinate per meter squared) and delay sowing (July). Therefore,

the selection of genotypes with greater resistance to plant lodging through genetic improvement remains the best alternative to reduce plant lodging under cultivation conditions.

In addition, a more significant increase in the TCL occurred in the genotypes when grown in environments 1,2 , and 3 . There was more significant photosynthetic radiation in these environments, and average temperatures were also higher, causing greater plant development. The smallest TCL and LFI values were observed in environments 7,8 , and 9 . This finding occurred primarily because of the delayed sowing (in July) compared to the other environments (sowing in June in both years of cultivation). With the gradual increase in the day's length, the oat plants developed faster, entering the reproductive stage earlier, resulting in less plant growth. In

these environments $(7,8$, and 9), there was also an increase in culm thickness (Figure 2d), especially in resistant genotypes, suggesting that faster growth combined with adequate photoperiod, temperature, and radiation, increases culm thickness. In environments 4, 5, and 6 , there were no significant differences between genotypes. This finding was possibly due to greater water availability and milder temperatures compared to 2017. 
The resistant genotypes showed higher culm thickness in environments 1, 7, and 9; the first two were due to the low sowing density and environmental influence during the year. In environment 9 , with sowing delay and higher plant density, genotypes susceptible to lodging were more sensitive to these management changes, which may result in even higher lodging rates.

The lodging-resistant genotypes showed more significant numbers of layers of subdermal parenchyma cells. Previous studies with wheat also found increases in parenchymatic tissues (Kong et al., 2013; Kelbert et al., 2004). Dunn and Briggs (1989) reported that the culm's stability increased with the thickness of the parenchyma layer in barley, and Palombini et al. (2016) found that the parenchyma was resistant tissue in bamboo. Thus, lodging resistance in the evaluated oat genotypes may be due to the presence of more developed parenchymatic tissues along the culm circumference. The other anatomical features were not directly related to lodging resistance, probably because they were more influenced by the environment, particularly the sowing time. In addition, lignin appeared in the parenchymal cells as a subdermal and cortical parenchyma (Figure $3 \mathrm{a}-\mathrm{d}$ ). This structural compound helps reinforce these culm tissues' cell walls, resulting in greater resistance to mechanical damage, especially in resistant genotypes, where they have developed subdermal fundamental parenchyma. In sorghum genotypes, lignin in parenchyma cells was also reported (Wilson, 1994).

The resistant genotypes visually presented higher lignin concentrations than the other genotypes (Figure $3 \mathrm{c}-\mathrm{d}$ ). However, in a previous study on wheat, Kong et al. (2013) found no differences in staining intensity in genotypes with varying levels of resistance. Köhler \& Spatz (2002) found that not all lignin types were mechanically important; therefore, the total amount is not necessarily a direct indication of more resistant culms. This finding corroborates our quantitative results (Supplementary Figure 4). There was no relationship between lodging resistance levels and quantitative levels of lignin in all evaluation environments in this set of genotypes. These results support the results obtained in other plants such as rice (Kashiwagi et al., 2006) and wheat (Kong et al., 2013).

Histologically, the most significant differences for cellulose were in the presence of a developed subdermal parenchyma (Figure $3 \mathrm{e}-\mathrm{h}$ ), suggesting that this compound may be important for lodging resistance in oats. Nevertheless, the cultivation environment appears to influence its color intensity and distribution pattern (Figure $3 e-h)$.

Although selection for lodging resistance is routine in most oat breeding programs, studies of the causes of lodging and resistance to lodging are rare in this specie. Knowledge of character associations with lodging resistance is essential to determine a character's genetic progress in a breeding program and whether the selection criteria are effective. Breeders have long encountered difficulties in identifying reliable and practical methods for determining lodging resistance in plants due to the environment's effects. In most breeding programs, the basis for comparing the genotypes in terms of resistance levels is the natural lodging occurring in strain testing fields in various places and years of testing and the plants' height. This phenomenon does not occur in all harvests does not occur uniformly in the field. 
There should be future studies evaluating specific methods for quantifying lignin and especially cellulose. A greater number of genotypes with greater ranges of resistance should be tested. The differences between sowing densities did not provide sufficient evidence to prove the practical use of this type of oat cultivation management. Information related to the different years of cultivation or different sowing times should be better explored.

Except for the specific association of resistance with anatomy, length, and culm thickness in the first basal internode found in this study, there were no general associations applicable for most of the evaluated characteristics if taken as isolate characters. These findings demonstrate the complexity of lodging resistance. Based on our results, the most practical and easily selectable feature for lodging resistance in a breeding program remains plant height together with culm thickness in the first basal internode. Our results also suggest the need for further research on the structural components of the cell wall and tissues and the role of the parenchyma in lodging resistance.

\section{Conclusion}

Shorter culm length and larger culm thickness in the first expanded basal internode are morphological characteristics associated with lodging resistance in Avena sativa. The evaluated genotypes did not show differences in culm diameter.

In the tested genotypes, there were no differences in lignin and cellulose contents; however, there were differences in resistance and susceptibility to lodging among genotypes, both in the distribution pattern and in the intensity of staining of lignin and cellulose. Except for the number of layers of cells in the subdermal parenchyma, all anatomical characteristics were influenced by the environment.

Higher temperature, greater photoperiod, and higher radiation lead to increased culm length, which may cause higher lodging rates in the field. On the other hand, the delay in sowing leads to decreased culm length, which may decrease the observed lodging intensity, and increase the grain yield.

\section{Declarations}

Funding: Jéssica Argenta has received scholarship to the Coordination Agency for the Improvement of Higher Education Personnel (CNPq). Research Support has received from Foundation of the State of Rio Grande do Sul (FAPERGS) for the research funding (Pronex 16/2551-0000484-6).

Conflicts of interest/Competing interests: There are no conflicts of interests.

Availability of data and material: The datasets generated during and/or analysed during the current study are available from the corresponding author on reasonable request.

Code availability. Not applicable 
Authors' contributions: All authors contributed to the study conception and design. Material preparation, data collection and analysis were performed by Jéssica Argenta, Marcelo Teixeira Pacheco, Jorge Ernesto de Araujo Mariath and Luiz Carlos Federizzi. The first draft of the manuscript was written by Jéssica Argenta and all authors commented on previous versions of the manuscript. All authors read and approved the final manuscript.

Ethics approval: Not applicable

Consent to participate: all the participants participate in this work.

Consent for publication: all the participants consent to publish this work.

\section{Acknowledgments}

The Coordination Agency for the Improvement of Higher Education Personnel for the scholarship to the first author of this study and the Research Support Foundation of the State of Rio Grande do Sul for the research funding (Pronex 16/2551-0000484-6). Thanks to the UFRGS oat breeding program and the LaVeg of the UFRGS Biosciences Institute for granting study materials.

\section{References}

1. Berry PM, Griffina JM, Sylvester-Bradley R et al (2000) Controlling plant form through husbandry to minimize lodging in wheat. Field Crops Research, Amsterdam, v.67, p.59-81, 2000. https:/ https://doi. org/10.1016/S0378-4290(00)00084-8/doi.org/10.1016/S0378-4290(00)0 0084 - 8

2. Berry PM, Spink J (2012) Predicting yield losses caused by lodging in wheat. Field Crop Research Amsterdam v 137:19-26

3. Berry PM, Sylvester-Bradley R, Berry S (2007) Ideotype design for lodging-resistant wheat. Euphytica, Wageningen, v. 154, p.165-179. https://doi.org/ /10.1016/j.fcr.2012.07.019.2012.07.019

4. Dunn GJ, Briggs KG (1989) Variation in culm anatomy among barley cultivars differing in lodging resistance. Canadian Journal of Botanic, Washington, v.67, pg. 1838-1843. https://doi. org/10.1139/b89-232

5. EMBRAPA (1999) Empresa Brasileira de Pesquisa Agropecuária. Sistema brasileiro de classificação de solos -. EMBRAPA, Rio de Janeiro, 412p

6. Fontaneli RS, Fontaneli RS, Santos HP et al (2012) Gramíneas forrageiras anuais de inverno. In: Fontaneli, R.S. Fontaneli R. S., Santos, H. P. (ed). Forrageiras para integração lavoura-pecuáriafloresta na região sul-brasileira. 2a ed. Brasília: Embrapa,. p. 127-172

7. Foulkes MJ, Slafer GA, William J et al (2011) Raising yield potential of wheat. III. Optimizing partitioning to grain while maintaining lodging resistance. Journal of Experimental Botany, v. 62, n. 2, p. 469-486. https://doi.org/10. 1093/jxb/erq300

8. Kashiwagi T, Madoka Y, Hirotsu N, Ishimar K (2006) Locus prl5 improves lodging resistance of rice by delaying senescence and increasing carbohydrate reaccumulation. Plant Physiology Biochemestry, 
Amsterdam, v. 44 n. 2, p. 152-157, 2006. https://doi.org/10.1016/j.plaphy.2006.02.004

9. Kelbert AJ, Spaner D, Briggs KG, King JR (2004) The association of culm anatomy with lodging susceptibility in modern spring wheat genotypes. Euphytica, Wageningen v.136, p.211-221, 2004. https://doi.org/10.1023/B:EUPH.0000030670.36730.a4

10. Hammer. O, Harper DAT, Ryan PD (2001) Past: Paleontological Statistics Software Package for Education and Data Analysis. Palaeontologia Electronica, vol. 4, issue 1, art. 4: 9pp., 178kb2001

11. Köhler L, Spatz HC (2002) Micromechanics of plant tissues beyond the linear-elastic range. Planta, v. 215 , n. 1, p. 33-40, 2002. doi: 10.1007/s00425-001-0718-9

12. Eryan Kong E, Liu D, Guo X et al (2013) Anatomical and chemical characteristics associated with lodging resistance in wheat. Crop Journal, Madison, v. 1, n. 1, p. 43-49. https://doi.org/10.1016 /j.cj.2013.07.012

13. Lima UM (2019) Barreiras fitossanitárias sobre as importações no brasil: o caso da aveia. In: Instituto de Pesquisa Econômica Aplicada, 2019. http://www.ipea.gov.br/portal/index.php?option = com_content\&view $=$ article\&id $=34457 \&$ ltemid $=432$. acessed in: 16 de junho de 2019

14. Felipe Luis Palombini FL, Kindlein W Jr, Oliveira BF, Mariath JEA (2016) Materials Characterization Bionics and design: 3D microstructural characterization and numerical analysis of bamboo based on X-ray microtomography. Materials Characterization v 120, 357-368. https://doi.org/

10.1016/j.matchar.2016.09.022

15. Pinthus MJ (1967) Spread of the Root System as Indicator for Evaluating Lodging Resistance of Wheat. Academic Press, Cambridge, vol 7, n. 2, p. 3-6. https://doi.org/10.2135/cropsci1967.0011183X000700020005x

16. Sas Institute (2000) SAS/STAT software: changes and enhancements through release 8.0. Cary: Statistical Analysis System Institute, 1167p

17. Silva DJ, Queiroz AC (2009) Análise de Alimentos: Métodos Químicos e Biológicos. $3^{\circ}$ Ed. UFV, Viçosa

18. Shah AN, Tanveer. M, Rehman A et al (2017) Lodging stress in cereal-effects and management: an overview. Environmental Science and Pollution Research, v. 24, n. 6, p. 5222-5237, 2017. https://doi.org/ 10.1007/s11356-016-8237-11.1007/s 11356-016-8237-1

19. Stapper M, Fischer RA (1990) Genotype, sowing date and plant spacing influence on high-yielding irrigated wheat in southern New South Wales. II.* Growth, yield and nitrogen use. Australian Journal of Agricultural Research, v. 41, n. 6, p. 1021-1041. https://doi.org/10.1071/AR9901021

20. Tams AR, Mooney SJ, Berry PM (2019) The Effect of Lodging in Cereals on Morphological Properties of the Root-Soil Complex. In Australian New Zealand Soils Conference, 3rd. 2004. Sydney.

Proceedings of the SuperSoil, Sydney 2004: p. 1-8. http://www.regional. org.au/au/asssi/supersoil2004/s9/oral/1998_tamsa.htm. Acesso em: 9 de maio de 2019

21. Tripathi SC, Sayre KD, Kaul. JN, Narang RS (2003) Growth and morphology of spring wheat (Triticum aestivum. L.) culms and their association with lodging: Effects of genotypes, $\mathrm{N}$ levels and ethephon. Field Crops Research, v. 84, n. 3, p. 271-290. https://doi.org/10. 1016/S0378-4290(03)00095-9 
22. USDA. United States Department of Agriculture Foreign Agricultural Service. Grain: World Markets and Trade. abril, 2020

23. Wang J, Zhu J, Lin Q et al (2006) Effects of stem structure and cell wall components on bending strength in wheat. Chinese Science Bulletin, v. 51, pg. 815. https://doi.org/10.1007/s11434-0060815-z

24. White EM (1995) Structure and development of oats. In: WELCH RW (ed) The oat crop: Production and utilization. Chapman \& Hall, London, pp 88-119

25. Wilson JR, Mertens DR, Hatfield RD (1993) Isolates of cell types from sorghum stems: Digestion, cell wall and anatomical characteristics. Jounal of the science of food and agriculture, New York, v. 63, p. 407-417. https://doi.org/10.1002/jsfa.2740630406

26. ZHU L, Shi GX, Li ZS et al (2004) Anatomical and chemical features of high-yield wheat cultivar with reference its parents. Acta Botanica Sinica, v. 46, n. 5, p. 565-572, 2004

27. ZUBER U, Wnzeler H, Messmer MM et al (1999) Morphological traits associated with lodging resistance of spring wheat (Triticum aestivum L.). Journal of Agronomy and Crop Science, Amsterdam, v. 182, n. 1, p. 17-24. https://doi.org/10. 1046/j.1439-037x.1999.00251. x

\section{Figures}

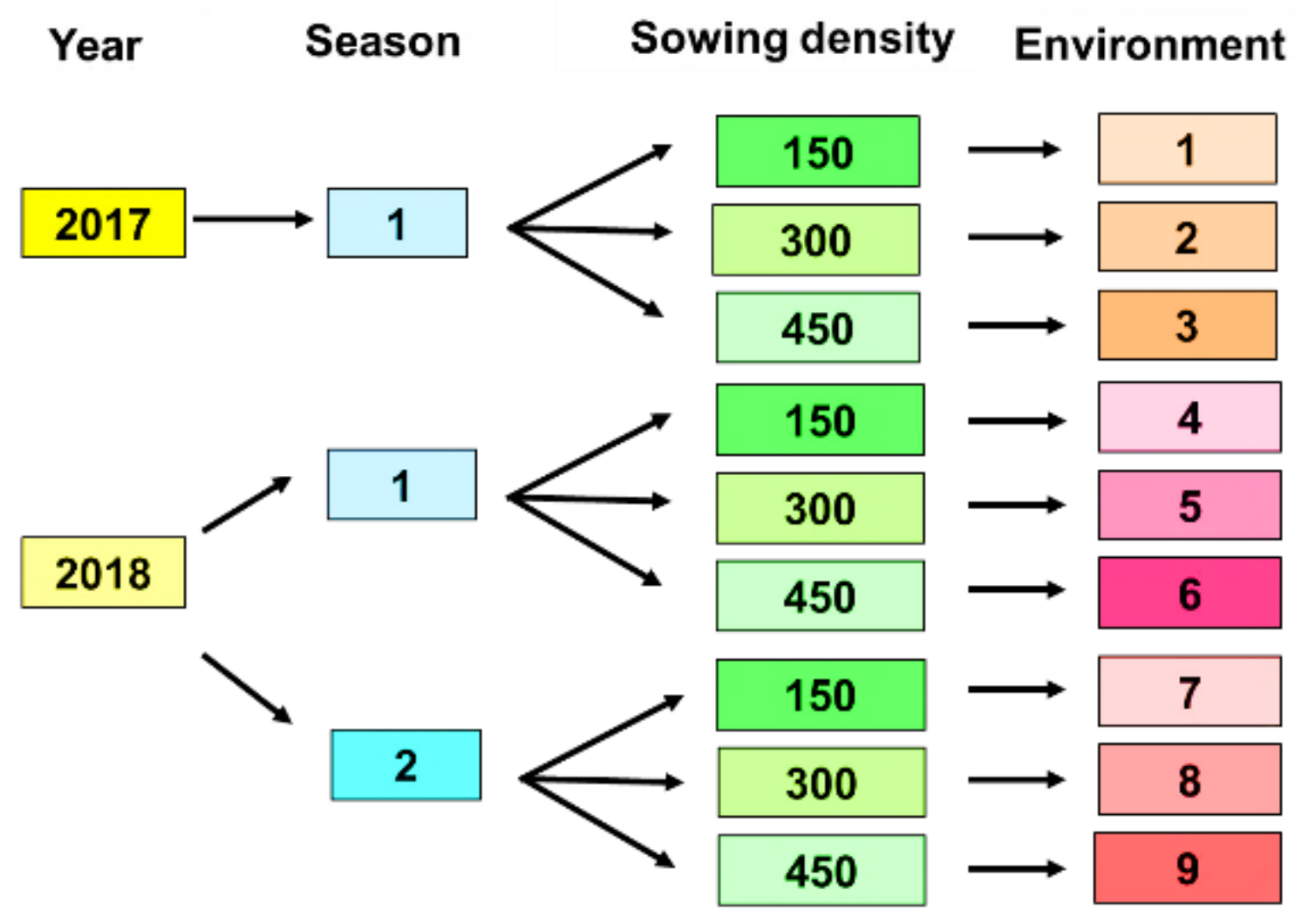

Figure 1 
Scheme of the environments evaluated in the study. Sowing density: 150 seeds able to germinate per meter squared; 300 seeds able to germinate per meter squared; 450 seeds able to germinate per meter squared. Season 1: Sowing on June 21 st; Season 2: sowing on July 13th.
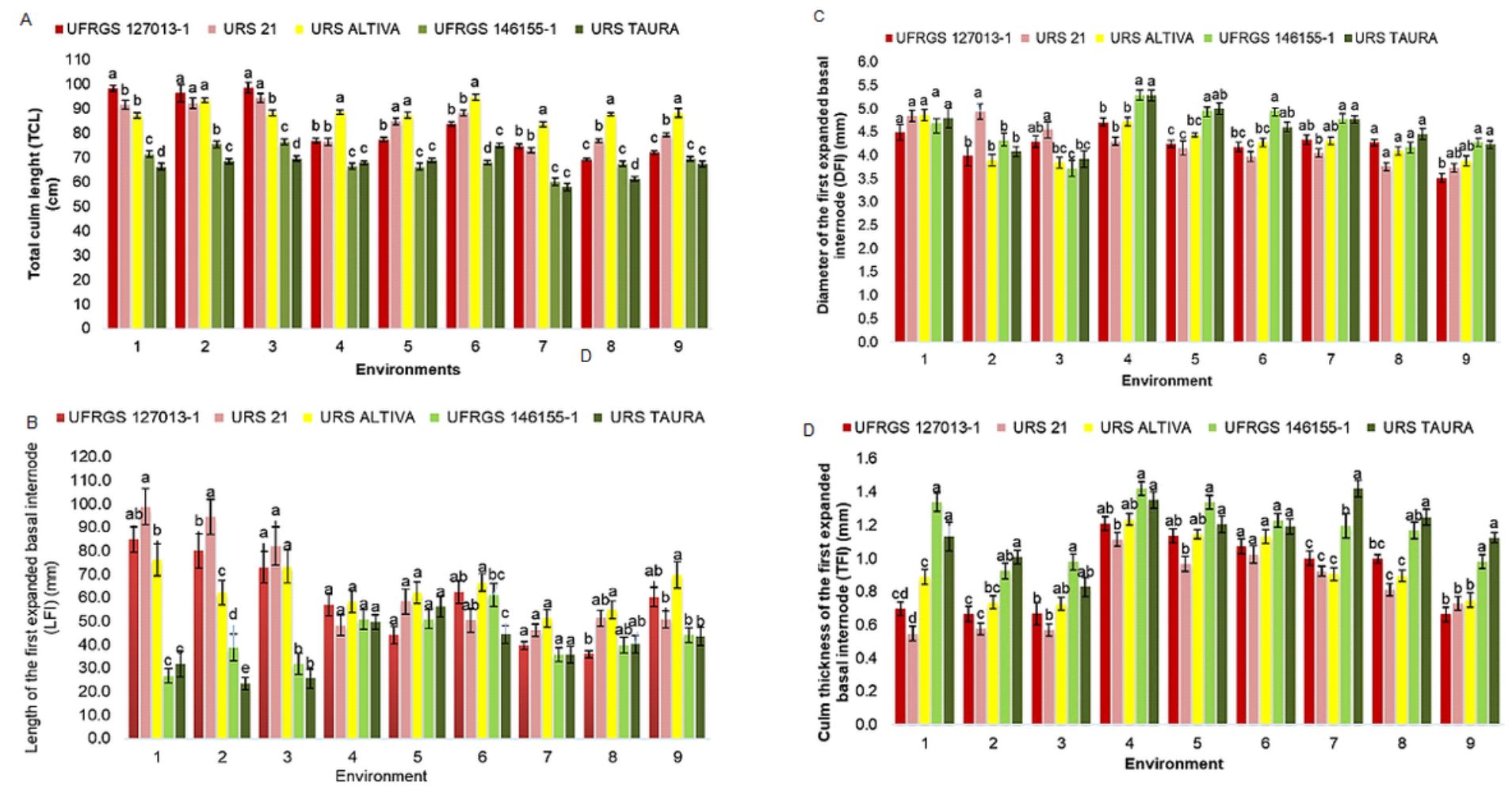

\section{Figure 2}

Avena sativa genotypes average under nine different environments (E1-E9) for the characteristics: A) Total culm length (TCL) (cm); B) Length of the first expanded basal internode (LFI) (mm); C) Diameter of the first expanded basal internode (DFI) (mm); D) Culm thickness of the first expanded basal internode $(\mathrm{TFI})(\mathrm{mm})$. Bars represent the standard error of the mean. Averages followed by the same letter do not differ by Duncan's test between genotypes within the same environment. $p=0.05 . n=825$. 

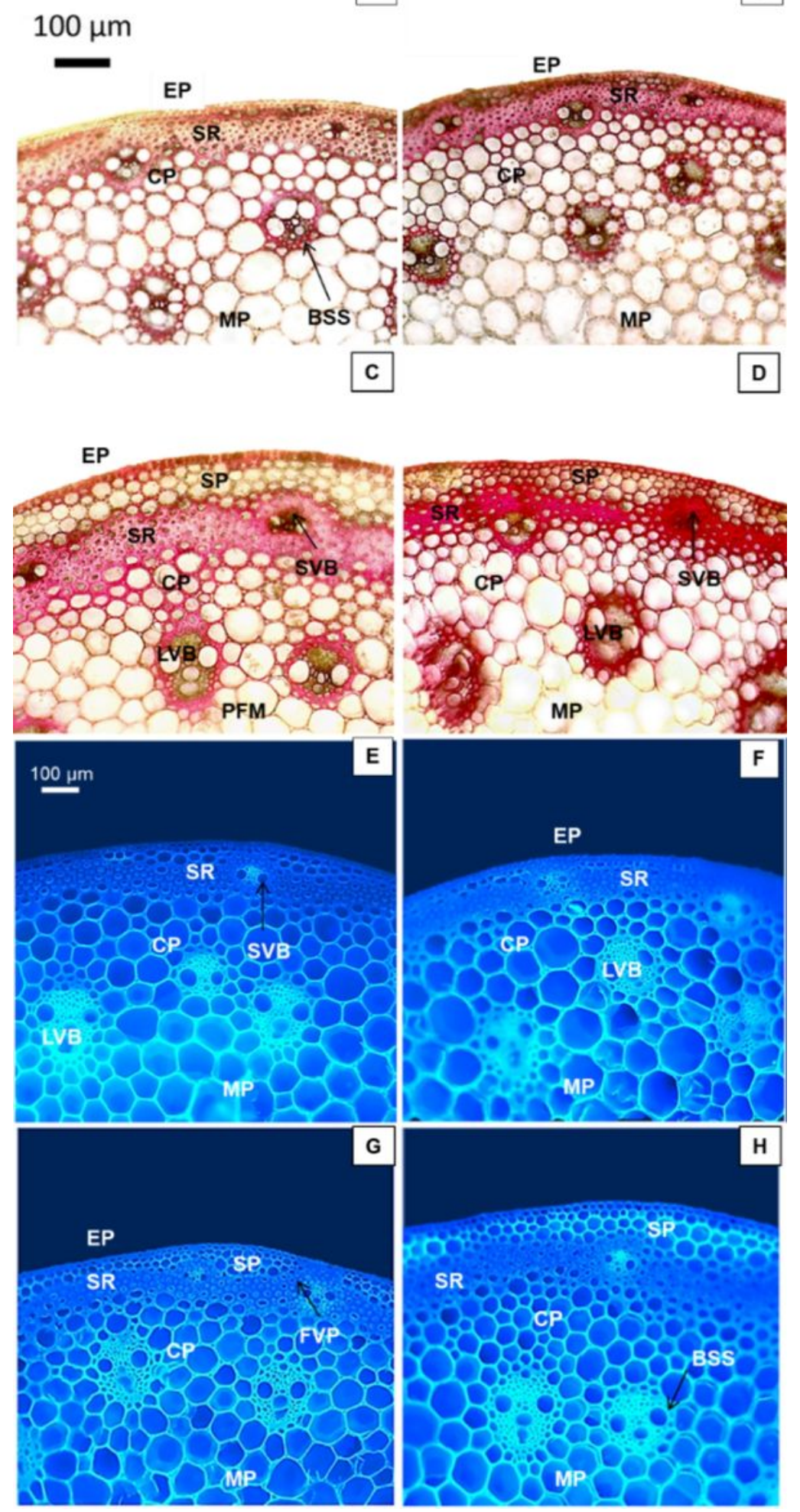

\section{Figure 3}

A - D: Cross-sections of the first expanded internode, reacted with phloroglucinol $+\mathrm{HCl}$, showing anatomical characteristics and deposition of lignin (reddish color) in different oat genotype tissues, under optical microscopy with 10X magnification (100 $\mu \mathrm{m}$ scale); $\mathrm{E}-\mathrm{H}$ : Cross-sections of the first expanded internode, reacted with calcofluor showing anatomical characteristics and cellulose deposition on the cell wall of various tissues of oat genotypes, under optical microscopy at 10X magnification (100 $\mu \mathrm{m}$ scale). 
The density of 300 seeds suitable for meters squared and two growing environments in 2018. A and D: UFRGS 127013-1 sowed in the typical growing season; B and F: UFRGS 127013-1 sowed in the late cultivation season in 2018; C and G: URS Taura sowed in the typical growing season; D and H: URS Taura sowing in the late growing season; EP: epidermis; SP: subdermal parenchyma; SR: sclerenchymal ring; CP: cortical parenchyma; MP medular parenchyma; SVB: small vascular bundles; LVB: large vascular bundles; BSS: bundle sheath sclerenchyma.

\section{Supplementary Files}

This is a list of supplementary files associated with this preprint. Click to download.

- Supplementarmaterial.docx 